\title{
ON THE PROPERTY RIGHTS SYSTEM OF THE STATE ENTERPRISES IN CHINA
}

\author{
Wang Liming* and LiU Zhaonian† \\ Translated by Fu Xiaoshuang and Wu Yanlei
}

\section{INTRODUCTION}

The state enterprises of new China, which are also called enterprises owned by all the people, were established primarily through confiscation of bureaucratic capital and enemy property, ${ }^{1}$ and by redeeming and reforming capitalist industry and commerce. By 1956, China had set up a socialist public ownership system led by the state-run economy. In the more than thirty years since the founding of the People's Republic of China ("PRC"), Chinese staterun enterprises have developed continuously as economic construction has unfolded. By 1985, the output value of state-run enterprises had reached 70.4 percent of China's industrial output; ${ }^{2}$ retail sales of commodities by state-run commercial enterprises had reached 40.4 percent of the total; ${ }^{3}$ the fixed assets of all state-run enterprises amounted to 737.05 billion yuan. ${ }^{4}$ The total number of state-run industrial enterprises in the country is $90,700 .^{5}$ The 8,285 large and medium sized enterprises account for 2 percent of the total number of industrial enterprises and 43 percent of the industrial output value, and through their profits and taxes, 42.7 percent of the state's income. ${ }^{6}$ Because of this, the authors hold that the state-run enterprises are the basis of China's socialist economy and the main economic lifeline of the country.

Copyright $\mathbb{C} 1989$ by Law and Contemporary Problems

* Associate Professor, Law Department, The People's University of China. He is co-author of Issues of Theory in Economic Law and New Theory of Civil Law.

$\dagger$ Post-graduate in civil law, Law Department, The People's University of China. His main work is Civil Legal Act.

1. As early as October 1947, the Chinese Communist Party published The Manifesto of the People's Liberation Army, which called for "the confiscation of the property of Jiang Jieshi (Chiang Kaishek), of Song Ziwen (Mme. Jiang Jieshi's brother), of Kong Xiangxi (Song Ziwen's brother-inlaw), of Chen Lifu and his brother (Jiang's chief ideologists), and of the other chief war criminals, and the confiscation of bureaucreatic capital." In February 1951, the Central Government promulgated the directive on the confiscation of the property of war criminals, Chinese collaborators, bureaucratic capitalists, and counter-revolutionary elements. Accordingly, within a short period after the establishment of the People's Republic of China ("PRC") in 1949, the factories, banks, mines, stores, and other businesses that had originally belonged to the Nationalist government and bureaucratic capitalists were confiscated and changed into state run enterprises. At that ime, this sort of enterprise constituted about $80 \%$ of the fixed capital in industry, transportation, and light industry.

2. See 3 Zhongguo jingji nianjian (China's Economic Yearbook) 19

3. Id. at 59 .

4. Id. at 11 .

5. Id. at 18 .

6. Renmin ribao (People's Daily), Apr. 28, 1987, at 1. 
Because the important long-term task of Chinese civil law is to adjust the property rights relations of the state-run enterprises, the property rights system of the state-run enterprises has become an important issue in Chinese civil law. This article will focus on the property rights system of the Chinese state-run enterprise and will not address other issues concerning other types of enterprises' property rights.

II

The Chinese Property Rights System of State-run

ENTERPRises in the Development of the Reform of THE ECONOMIC SYSTEM

The reform of the Chinese economic system began with the Third Plenum of the Eleventh Central Committee of the Communist Party of China held at the end of 1978. Before then, the property rights of state-run enterprises essentially followed the Soviet model of the Stalin era. The basic characteristics of this system were an emphasis on the centralized and unified management of state-run enterprises by the state executive units from the central government to various local governments. The enterprises themselves had no independent property rights: The production tasks of state-run enterprises were set by mandatory goals established by the central government. All state-run enterprises, regardless of the appropriateness for its particular situation, were to implement the plan; all the gains and expenses are managed centrally by the state; all the profits of state-run enterprises are submitted to the state. Moreover, even most of the depreciation expenses are also submitted to and managed by the state; all the expenditures are covered by the state and specific funds can be spent only on specific purposes and cannot be adjusted. All raw materials needed by the state-run enterprises are distributed by the state. All products are priced, bought, and sold by the state. The state shoulders the losses and unlimited liabilities of state-run enterprises. ${ }^{7}$ Besides, things like the appointing and removing of the management personnel, the organization of labor, the distribution of the workers' earnings, technology innovation, and expansion are all decided by the executive units in charge of the state government, and the enterprises themselves have no power to make any decisions. ${ }^{8}$ Under such a situation, the enterprises have neither the status of legal personality nor independent property rights. This property rights system results from our long neglect of the objective existence of commercial economy and our view that socialist economy is a natural result. Accordingly, the previous Chinese civil law theory commonly held that since the property rights of the state-run enterprises is the major content of the state ownership, the state itself is the sole owner of state property. No other enterprises and institutions could be

7. Xue Muqiao, Zhongguo Shehui zhuyi Jingji Wenti yanjiu (Research on Issues in China's Socialist ECONOMY) 192 (rev, ed. 1983).

8. Society for Research of China's Reform of the Economic System, Zhongguo JingJ tizhi gaigede xin moshi (New Forms in the Reform of China's Economic System) 186 (1984). 
regarded as the subject of the state ownership. ${ }^{9}$ This is the so-called sole theory of state ownership in the Chinese civil law. In addition, as state ownership can be exercised or controlled only by the People's Republic of China, no other enterprises or institutions have the right to exercise the ownership rights of the state property. ${ }^{10}$ This is usually called the unification theory of the state property. In fact, these theories denied the facts that staterun enterprises should have their independent property rights and also should have their independent position. Both fit the highly centralized economic management system in China.

Enterprises are the cell of the social-economic formation. The vitality and dynamics of a social-economy are directly decided by the vitality of an enterprise, the key to which is its independent property rights. Under the previous economic system, enterprises had no independent property rights. Therefore, the state-run enterprises' property rights system is becoming the obstacle to the vitality of enterprises and saps the vitality of what ought to be a dynamic socialist economy. The main shortcomings of this property rights system are discussed below.

(1) The direct exercise of ownership rights over the property rights of state-run enterprises by state organs mixed together the property rights relations and the administrative relations between state and enterprise, thereby creating a situation in which state and enterprise become indistinguishable and administrative methods interfere in the production activities of the enterprises. This results in the ossification of social-economic activities and curbs the vitality and vigor of enterprises.

(2) The direct exercise of ownership rights over state-run enterprises by government organs led to the subordination of enterprises to the state government units, the formation of localism in economic life, the blocking of horizontal economic associations between enterprises, and the cutting of the links between the socialized production and commodity economy. These elements in turn made professional cooperation and exchange of funds, material, technology, and professionals among enterprises and regions impossible, thereby causing unchecked construction, duplicate production, and heavy financial losses for the state.

(3) The state's direct exercise of ownership rights and direct management of enterprises caused serious uncontrolled investment. Investors did not care about the return, and because enterprises have no independent property rights they naturally neglected the gains and losses of their capital. On the one hand, enterprises competed for investment and became diseased with "investment-hunger." On the other hand, nobody cared about the gains and losses of investment capital. Together, these tendencies caused a dangerous surge in basic construction and diminished the state's economic benefits.

(4) Because the state directly exercises ownership rights and directly manages enterprises, the government assumed the responsibility for profits and losses generated by the enterprises' production activities. As a result, the enterprises did not feel the pressure of competition and lazily became habituated to the security of the "iron rice bowl" and the "one big pot." Meanwhile, because the enterprises handed over to the state every penny they earned, and lacked a particular material interest, they did not have the ability to assume obligations. Since there was a great gap between on the one hand, the behavior of the enterprises, and on the other the material interests of the enterprises, the zeal, initiative, and creativity of the employees

9. Tong Rou, Zhao Zongfu \& Zheng lichun, Minfa gailun (Introduction to Civil Law) 97 98 (1982).

10. Tong Rou, Minfa yuanli (Basic Principles of Civil Law) 159 (1986). 
and the enterprises were greatly depressed. The resources of the state could not be fully utilized, and there was no possibility for realizing maximum economic efficiency.

The disadvantages of the former state-owned enterprise property rights system have already curtailed the enhancement of the social productivity of our country and slowed down the development of the national economy. Thus, since the Third Plenum of the Eleventh Party Central Committee (in 1978), the Party and state have launched a gradual reform of the economic structure that has been pursued in an orderly, step-by-step, planned manner. In respect to the economic reform in the cities, the key is the invigoration of the enterprises, the core of which is to expand the autonomy of the enterprises. ${ }^{11}$

In order to implement the policy of the Party to expand the autonomy of the enterprises, the State Council promulgated in July 1979 five important legal documents: The Regulations on the Expansion of Operational Management Autonomy for State-Owned Industrial Enterprises; ${ }^{2}$ The Regulations on Retention of Profits by State-Owned Enterprises; ${ }^{13}$ The Provisional Regulations on Levying Fixed Capital Tax in State-Owned Enterprises; ${ }^{14}$ The Provisional Regulations on Acceleration of Depreciation of Fixed Capital for State-Owned Enterprises and Improvement of the Usage of the Depreciation Fund; ${ }^{15}$ and The Provisional Regulations on Adoption of Loan and Credit Methods for Floating Capital in Industrial Enterprises. ${ }^{16}$ The five documents have provided important legal guidelines for the reform of the property rights system in state-owned enterprises, and thus caused significant changes in the system. The following are the major changes:

First, enterprises now have certain rights in planning and managing production. Once they have met the prerequisite of fulfilling the state plan, enterprises may make a supplementary production plan, based on the availability of energy and raw materials, to meet the needs of construction and the demands of the market. The enterprises can also sell the products manufactured under the supplementary plan on their own at the price regulated by the state. When there is a surplus of production capacity, the enterprises can undertake cooperative production for other enterprises, making products for other enterprises with materials supplied by those enterprises.

Second, enterprises can now retain a portion of the profits they make. When the enterprise has made profits, a portion, stipulated by regulation, may be retained. The enterprise can use the retained profit to establish funds for production development, collective welfare, and employee bonuses. The

11. Central Committee of the Chinese Communist Party, Guanyu jingji tizhi gaige (Resolution on Reform of the Economic System) 12.

12. Guanyu kuoda guoying qiye jingying guanli zizhu gaige ruogan guiding.

13. Guanyu guoying qiye shixing lirun liuchengde guiding.

14. Guanyu kaizheng guoying gongyeqiye guding zichanshuide zanxing guiding.

15. Guanyu tigao guoying gongyeqiye guding zichan zhejiu he gaijin zhejiufei shiyong banfade guiding.

16. Guanyu guoying gongyeqiye shixing liudong zijin quan'e xindai zanxing guiding. 
larger the profits, the more the enterprise can keep. Hence, there is to a certain degree a link between the performance and development of the enterprise and the material interest of the employees.

Third, the depreciation rate has been accelerated. Most of the fund accumulated through depreciation can be retained by the enterprises, while the rest of it can be used by the enterprise's supervisory department in other related subordinate enterprises.

Fourth, enterprises now have to pay to the state a tax on fixed capital they possess. It is a system of paying for the possession and use of fixed capital. Accordingly, the enterprises have the right to transfer or lease the surplus fixed capital.

Fifth, all floating capital the enterprises need will be provided by banks through the form of loans, with the enterprises paying interest for using floating capital.

Sixth, enterprises now have the right to apply to central or local authorities to export their own products. Part of the foreign exchange earned through export can be retained according to the relevant state regulation. The retained foreign exchange can be used by enterprises to import necessary technology, equipment, and material or to send personnel abroad to study or receive training.

Seventh, according to the regulations, no unit or individual has the right to appropriate funds from enterprises except where there is an explicit authorization from the relevant authorities, nor can those units or individuals remove personnel, equipment, material, or capital from the enterprises.

Since implementation of the method of retention of profit and responsibility for losses, the property rights of enterprises have improved significantly. Although there have been changes, the enterprise property right still is not guaranteed because the enterprise has not freed itself from the interference of various supervisory administrative organs, which at each level deduct a relatively large share of the profits. To overcome this shortcoming, the state has undertaken two steps since 1983 to change the way enterprises retain profits. The first step was to implement the method, "Substitute tax for profits; maintain both tax and profits." In April 1983, the state promulgated Implementation Rules on Converting State-Owned Enterprise Profit Submission into Taxation ${ }^{17}$ and Temporary Regulations on Levying Ownership Tax on State-Owned Enterprises. ${ }^{18}$ The second step is to change the method of making a combined payment of profits and taxes to the state into one in which the enterprise pays taxes according to a schedule of eleven stipulated types of taxes. After paying taxes, the enterprises can allocate the profit according to their needs. To accomplish this, the state promulgated Second Stage Provisional Rules on Converting State-Owned Enterprise Profit Submission into Taxation and Regulations Regarding

17. Guanyu dui guoying qiye zhengshou suodeshuide zanxing guiding.

18. Guanyu zai guoying qiye tuixing ligaishui di'erbu gaigede baogaode tongzhi. 
Income Taxes for State-Owned Enterprises of the People's Republic of China (Draft) in September 1984. ${ }^{19}$ With the implementation of the second step, the state revenue formerly generated through both profits and taxes remitted by the enterprises has been changed into a single tax resource. Now that enterprises that have paid their taxes to the state have more power to manage their property and finances, the material conditions have been created for the enterprise truly to separate the functions of administrative organ and entrepreneurial entity.

When implementing this change from submission of profits to payment of taxes, the State Council promulgated in April 1983 The Provisional Regulations on State-Owned Enterprises ${ }^{20}$ and in May 1985 the State Council promulgated The Provisional Regulations Regarding Further Expansion of the State-Owned Enterprises' Autonomy. ${ }^{21}$ Furthermore, in 1985 the State Council promulgated The Provisional Regulations to Enhance the Vigor of Large- and Medium-Size State-Owned Industrial Enterprises, ${ }^{22}$ and in 1986 it promulgated The Regulations Regarding Encouraging Horizontal Economic Cooperation. ${ }^{23}$ The promulgation of these regulations has brought about new changes to the enterprises' property rights system:

(1) Former laws and regulations recognized only the rights of enterprises to possess, to utilize, and to profit from the property the enterprises occupied. There was little right to dispose of the property. According to the new regulations, enterprises can have broader rights to dispose of the property in two respects: first, the right to dispose of the fixed capital property. In accord with the relevant regulations, enterprises can lease or transfer, in return for compensation, the surplus set capital property. If those properties include advanced and sophisticated equipment that is under the direct control of superior departments, authorization should be obtained at the time of transfer or lease. The income from transfer or lease can be used to upgrade the enterprise's technology or equipment. The enterprises can also contribute machines and equipment they possess as investment when they engage in cooperation with other units.

Second, the right to dispose of its floating capital. The profits retained by the enterprise after taxes will be distributed per the proportions set by state regulations to establish funds such as production development fund, new products trial production fund, reserve fund, employee welfare fund and employee bonus fund. The remaining profit can be disposed of at the enterprise's discretion. The enterprises can also use the temporarily uncommitted production development funds for investment in joint ventures, cooperation, compensation trade, and so forth.

Third, the right to dispose of commodities. Except for those products the state does not allow the enterprise itself to sell, the enterprise can sell the portion of the products that are retained by the enterprise under state plan, surplus products resulting from increased production, new trial products, products that are not procured under the plans by the commercial sales units, and inventory overstock. The enterprise may also sell a stipulated portion of key products normally subject to unified distribution by the state. It also has the right to set the price for those industrial production materials that it sells on its own. The enterprise can also transfer for compensation its inventions, technology improvements, and innovations

19. State Council, Guoying qiye dierbu ligaishui shixing banfa (Trial Rules for the Second Stage of Converting State Enterprise's Profits to Taxes) 9.1984, art. 1.

20. Guoying gongyeqiye zanxing tiaoli.

21. Guanyu jinyibu kuoda guoying gongyeqiye zizhuquande zanxing guiding.

22. Guanyu zengqiang dazhongxing guoying gongyeqiye huoli ruogan wentide zanxing guiding.

23. Guanyu jinyibu tuidong hengxiang jingji lianhe ruogan wentide guiding. 
to other domestic enterprises, or, with permission from the relevant department at the State Council, to apply for foreign patents, or to export those inventions abroad.

(2) The former laws and regulations did not allow mutual investment among enterprises, or formation of new enterprises through mutual associations. According to the new regulations, enterprises can voluntarily engage in horizontal economic associations without the former restrictions of boundaries between regions, departments, and industries. The difference between state ownership and collective ownership will no longer hinder cooperation between different enterprises. One may implement affiliations for specialization, or for personnel, resources, capital, technology, or even for sales. If the enterprises involved in associations use original factory buildings, facilities and technology, patents, or trade marks as shares of investment, their monetary value will not be calculated as part of the fixed capital allowed by the state plan. The joint organization's internal production construction and material distribution quotas can be accounted for by the two parties. In financing, it is allowed now for the specialized banks to make fixed capital loans across regions and specialties to those economic cooperation organizations, provided that the loans would not exceed the scale or amount of fixed capital investment regulated by the state plan. Loans obtained can be put into internal mutual investment. Floating capital loans can be obtained through direct channels the enterprises are formally assigned to, or can be adjusted through coordination among the parties involved. There shall be no double taxation for such cooperation, and state-owned enterprises will not pay an adjustment tax for profits generated from the cooperation. For five years, profits resulting from investment in transportation, energy industry, or investment in poor, isolated, inland rural regions would be subject to only half of the usual income tax rate. Profits reinvested in these regions and industries would be exempted from taxation. These measures affirm the right of the enterprise to allocate both fixed and movable property.

It ought to be noted that although the regulations promulgated by the administrative organs of the state during the economic reform have enriched and improved Chinese civil law's enterprise property right system, these regulations are administrative laws in nature. They are flexible rather than stable. In particular, these enactments have not, or cannot, affirm the legal status of the enterprise in a society of commodity economy. Without resolving this status, enterprises' property rights and liabilities are incomplete in a legal sense.

In order to consolidate the achievement of the economic reform and to promote the development of socialist commodity relationships in China, the Fourth Session of the Sixth People's Congress enacted The General Principles of Civil Law on April 12, 1986. The Standing Committee of the Sixth People's Congress in December, 1986 passed the State Enterprise Bankruptcy Law. ${ }^{24}$ The promulgation of these two important civil law codes has clarified the legal status of state-owned enterprises and set forth the property liabilities for state-owned enterprises. Article 41 of the General Principles provides that "state-owned enterprises and collective enterprises that meet the capital requirements provided by the state, possess a charter, an organizational structure and premises, and are able to assume civil obligations independently, acquire the status of legal person upon approval and registration by the responsible agency."

The General Principles also provides in article 48 that "the state-owned enterprise legal person bears civil liability to the extent of the property the State has given it to operate and manage." This means that after the state-

24. As per its article 43, the Bankruptcy Law went into effect on a trial basis three months after the promulgation of the State Enterprise Law on Aug. 1, 1988. 
owned enterprise obtains status as a legal person, the property in the enterprise has been separated from the property of the state and is distinct as well from the property of the member/employees of the enterprise. The enterprise has thus gained the property that is subject to its independent management. In regard to the property it owns, the enterprise has the right to possess, utilize, profit from, and dispose of it. Without an independent property right, it is hard for an enterprise to become a true legal person.

It is noteworthy that even though the General Principles has stipulated that the state enterprise, in its capacity as legal person, enjoys independent property rights and can bear civil liabilities, these provisions are not completely reflected in the provisions in the General Principles regarding the ownership rights to property. In other words, there is an inconsistency between the rules regarding the state enterprise's property rights and the rules regarding the state enterprise's status as a legal person. The General Principles provides in article 82 that "the right enjoyed by a state-owned enterprise to operate according to law state property that has been given to it to operate and manage is protected by law." The provision means that enterprises have the right to the management of the property rather than the right to the ownership. Moreover, the General Principles stipulates that the state grants management right to the enterprise. Consequently, it is easy for this sort of right to becorne a property right subordinate to the administrative rights of the state, one administrative organs can now restrict, now loosen. ${ }^{25}$ In respect to its content and scope, the enterprise's property management right is unstable. The actual experience of the reform in recent years shows that though enactments have defined the enterprise's rights, those rights have been curtailed by various levels of local government and supervisory administrative organs. "Loosening control over enterprises in public, tightening the control in private" became a commonplace phenomenon. Every government department and "administrative company" 26 has excuses for interfering with and levying exactions on enterprises. ${ }^{27}$ The enterprises' property rights have not been realized in practice, nor has their status as legal persons been guaranteed.

25. See Wang Liming \& Guo Feng, Guoyou qiye gufenhua yu guojia suoyouquan de biange (Securitization of State Enterprises and the Transformation of State Ownership Rights), in ZHONG QINGNIAN JINGYING LUNTAN (Young and Midde Aged Economists Forum), No. 6 (1986).

26. Companies with an administrative character (xingzhengxing gongsi) were produced in the course of the reform of administrative structure. Because of a reduction in administrative organs, some productive units which are no longer allowed to identify themselves as part of a particular administrative structure, call themselves a company, although in fact they remain part of an administrative organization. These units are called companies with an administrative character.

27. Wang Liming \& Guo Feng, Guoyou qiye gufenhua yu guojia suoyouquan (The Securitization of State Enterprises and the State's Ownership Rights), in Jingying GUanlizhe (MANagers), No. 12 (1986). 


\section{III}

\section{Discussion of the Nature of Enterprise Property Rights in China and The Viewpoint of The AUthors}

While the state has undertaken the reform of expanding enterprises' autonomy, there has been broad discussion among Chinese jurists on the nature of enterprise property rights in the state-owned enterprises. The issues are: Why does the enterprise have the rights to possess, use, profit from, dispose of the property granted to its control by the state? What is its theoretical basis? Under the demands of economic reform, what are the appropriate rights required by the enterprises, in regard to the property in their possession to meet practical needs?

\section{A. The Doctrine of Right to Possession}

This theory recognizes that the state has the ownership right to the property in the state-owned enterprises while the enterprises have the right to possession. ${ }^{28}$ This theory is based on Karl Marx's analysis of feudal land ownership. In commenting on the feudalist landlord economy, Marx said: " [T] he direct producer was not the owner but was the possessor, and all his labor under the law in fact belonged to the owner of the land."'29 Under the feudal system, when tenants cultivated the land, the ownership of the land and the possession of the land were in fact separated. The possessor of the land did not have the ownership of the land but the right to possession as if the land belonged to him. That is to say, the tenant had all the rights other than the right to dispose of the land. The right to possession was derived from the authorization of the land owner. Under this Marxist doctrine, it is the task of the economic reform to provide enterprises with comprehensive property rights so long as the means of production are owned by the state. The state, as the owner of the property, would have the final disposition right to the property, but at the same time enterprises as the possessor would have substantial allocation rights over the property of the owner - that is, the right to possession. Therefore, the right to possession is a relative or indirect ownership right.

Having recognized the disadvantages of the over-centralization of power in the Chinese economic system, this doctrine advocates that enterprises should be given a right to possession which would be separated from the state ownership. This is a correct starting point. However, as the doctrine derives its analogy from feudal natural economic conditions which had the feature of personal adherence to the land, it is not satisfactory to explain the total relationship of rights and liabilities in socialist commodity production

28. See Jiang Ping, Kang Deguan \& Tian Jianhua, Guojia you guoying qiye zhijiande caichan guanxi yingshi suoyouquan he janyouquan de guanxi (The Property Relationship Between the State and State Enterprises Must be a Relationship Between Property Right and Usufruct, in Faxue Yanjiu (Studies in Law), No. 4 (1980); Meng Qingguo, Lun zhanyou zhanyouquan gongneng he zhanyou quan, (On Possession, Function of Possession Right, and Possession Right), in Faxue yanjiu (Studies in Law), No. 2 (1985).

29. 3 K. MarX, Zibenlun (Capital) 893. 
activities. Furthermore, the doctrine miscomprehended the concepts of possession and "right to possession." Possession rights are in fact one of the functions stemming from ownership rights. "Since the possession right is one of the functions separated from ownership, it cannot exceed the scope it inherently has." 30 To conceptualize one function of ownership right as a relative ownership right will be logically absurd.

\section{B. The Doctrine of the Right to Operative Management (jingying guanli quan)}

This theory holds that the state has the right to own the property but the enterprise has the operative management right. The theory was first presented by the famous jurist and member of the Soviet Academy of Science, Wynijilatov, in his book The Ownership Right in Socialist Countries in 1948. Stalin quoted this concept when he was writing his 1950 book, The Soviet Socialist Economy. The concept was adopted formally in Soviet Civil Legislation Principles and the Soviet Russia Civil Code in 1961 and 1964, respectively. East European countries have adopted such a concept or developed it in different ways. For instance, the Hungarian Civil Code used the term "management right," and the Czechoslovak Economic Code used the term "the right to management of people's property," and so on. Article 82 of the General Principles is in fact recognition of the state enterprise's right of management. In China, many scholars support this concept ${ }^{31}$ which is clearly consistent with current legislation. ${ }^{32}$

This theory holds that the object of the management right is that of property, that is to say, enterprises can directly exercise the right to possess, utilize, and dispose of the property. Enterprises can benefit from the property through operative management. This right is derived from and depends on the state's right of ownership. Moreover, the scope of the functions of the right and the limits of the right have been prescribed by the state as the right holder of the ownership. Such a management right is a derivative right cast by the owner onto the property and is inferior to the state ownership. ${ }^{33}$

The authors' view is that the concept of an operative management right or the right to operate has confused the management right of the administrative

30. Wang Liming \& Li Shirong, Quanmin suoyouzhi qiye guojia suoyouquan wenti lanlun (An Inquiry into Problems in State Property Rights in Enterprises Owned by the Whole of the People), in ZhongGuO shEHUI kexue (Chinese Social Science), No. 1 (1986).

31. Wang Baoshu \& Cui Qinzhi, GongqiYe fa lungang (On the Industrial Enterprise Law) 40-41 (1985).

32. Some scholars argue that in the General Principles the right of operation (jingying quan) is not equivalent to the right of operative management (jingying guanli quan). "If the two sorts of rights are not separated, then inevitably the enterprise is the same as a level of administrative management (xingzheng guanli) and the enterprise becomes an appendage of the administrative organization (xingzheng jiguan)." See Tong Rou \& Zhou Wei, Lun guoying qiye guanli quan (A Discussion of the Management Right of State Enterprises), in Faxue yanjiu (Studies in LAW), No. 3 (1986). In our view, the operation right and the administrative right are both obtained from adminsitrative grants of power, so in fact there is no difference between the two.

33. See Wang Baoshu \& Cui Qinzhi, Gongye Qiyefa lungang (On the Industrial Enterprise LAW) $41-42$ (1985). 
organ with the enterprise's property right. This concept treats the enterprise's right as a product of authorization from an administrative organ. It militates against the separation of administrative organs and enterprise entities and is unresponsive to the demands of the reform. Furthermore, if the enterprise's property right is not recognized as a right necessary for the enterprise as producer and manager of commodities, enterprises would not be able to obtain a stable, well defined right to the property. In particular, if the enterprise enjoyed only the operative management right or the operative right, there would hardly be normal commercial exchanges between stateowned enterprises and collectively-owned enterprises. For instance, when such a transaction is undertaken, the state-owned enterprises could only transfer the operative management right over commodities, yet the collective could transfer the ownership right. When there is a horizontal cooperation in production, the state enterprises can invest in the cooperation only the right of operation but the collectives could use their ownership right to generate the capital. It would be absurd both in theory and in practice. If we recognize only the right of operation but not the right to ownership, it would be very hard to explain why state enterprises should bear the risk of bankruptcy when the enterprises could not balance their deficit with their capital. ${ }^{34}$

\section{The Doctrine of Trust in Management}

This theory holds that the state is the owner of the property but cannot directly manage the property. Based on its own interests and needs, the state can give the property to another person to manage and operate. When the state decides to entrust property owned by the people to the trustee (enterprise) to manage, and the trustee accepts the trust, the relationship between the state and the enterprise has become a relationship of trustor and trustee. The trustor has the right to give trust to the trustee to manage the property and the trustee has the right to manage the property as the trust relationship so describes. ${ }^{35}$

These authors maintain the view that the doctrine of trust management is trying to explain the relationship between the state and the enterprise as an equal civil relationship while denying that the enterprise property right is based on an authorization from an administrative organ. However, it is obvious that this doctrine is derived from the common law trust system, one inappropriate for relations between the state and enterprises. Because the enterprise is established by the state, it cannot exist totally independently of the state. In the period before the ownership rights and administrative rights enjoyed by the state are separated, there will still be the appearance of a state with a dual identity as owner and administrative organ. It will be hard to

34. See Wang Liming, Lun shangpin suoyouquan (On Commodities Ownership), in Faxue yanjiU (Studies in Law), No. 2 (1986).

35. Jin Ping \& Chao Yongshan, Guojia caichan quan yu weituo jingying quan (The State's Property Rights and the Right to Entrust Management Right), in Zhongguo faxue (China's Jurisprudence), No. 4 (1985); Zhao Wanyi, Lun weituo jingying quan (On the Entrusting of Management Right), in GuojIA suoyouquan lunwenji (Colifected Essays on the State's Ownership Right) (1987). 
maintain an equal civil relationship between the state and the enterprise. Furthermore, there are no clear theoretical explanations as to whether the assigner of operational right (trustor) and the receiver of that right (trustee) are rights of obligation or of property.

\section{The Doctrine of Usufruct (The Right of Beneficial Use of Property)}

The theory holds that the state has the ownership right in state enterprise property, but the enterprise has usufruct. ${ }^{36}$ Pinning the shortcomings of the situation in China on the fact that enterprises do not have an economic interest in the property and suffer too much interference from administrative organs, this theory treats the enterprise's right in the property it is managing as usufruct. Usufruct means that the non-owner of the property will get an interest in utilizing and benefitting from the property as of right. The theory holds that usufruct can be shown in several aspects: The state enterprise's use right in the property is produced by the state's action of creating the enterprise. Once the enterprise is established, it gains usufruct in the property the state authorizes it to manage. Once usufruct is established, the right of possession, use, and benefit will be transferred to the possessor of the usufruct, that is, the enterprise. The enterprise will also have the right to dispose the floating capital.

As owner, the state retains the ultimate right to recover the fixed capital and the value of the floating capital. This is the right to withdraw property or value as the owner of the property in its pure form. The state, based on its sole ownership right over state enterprise property, has the right to plan the production guidelines, issue the order of production plan, supervise the production activities, and collect the value of depreciation of fixed capital. The state also has the right to withdraw all fixed capital and floating capital when the enterprise is closed down. As holder of the usufruct, the enterprise has the right to conduct its production activities independently, and to possess, utilize, and dispose of the floating capital in the enterprise. The enterprise also has the right to allocate as it sees fit the post-tax profits it retains.

The authors think that it is correct to regard usufruct as stressing the economic realization of the state's ownership and the economic benefit the enterprise ought to enjoy. However, it is still not satisfactory to summarize the enterprise property right as simply another right in the traditional civil law concept of usufruct. First, the enterprise's property right is not like usufruct, for the enterprise cannot seek to benefit only itself from the state's property. Also, even if usufruct is established, the state's ownership right cannot become a "simple ownership right" or a "hollow right." Second, usufruct is produced on the basis of contract. Its duration is limited, and the enterprise's property right is established and diminished according to law. Its very

36. See Li Kaiguo, Guoying qive caichan quan xingzhi tantao (An Inquiry into the Character of State Enterprise Property Right), in Faxue yanjiu (Studies in Law), No. 2 (1982). 
existence and continuation will depend on the demand of the society and the outcome of the management of itself. There is no definite time requirement in it. Third, usufruct cannot include all the competence embodied in the state enterprise's property right. The enterprise's exercise of property rights is not limited only to profit but includes the right of disposition of the property, which traditional usufruct cannot ever contain. Therefore, the concept of usufruct cannot explain the fact that the enterprise has a definite right to dispose of state property.

\section{E. The Doctrine of Total Ownership Right}

This theory advocates abolishing the state's ownership right and turning over enterprise property to enterprise ownership. With the preconditions that enterprises shall abide by the law, guarantee the expansion and accumulation of the enterprise property, and respect social interest, the enterprise shall have the right to possess, utilize, and dispose of property as independent owner of the property. The relationship between the state and the enterprise becomes purely one of obligation. ${ }^{37}$

The positive implication of the doctrine is that it can prevent administrative interference from the state and realize the separation of government and enterprise. It can also guarantee the role of the enterprise as a producer and exchanger of commodities with the independent status of legal person. However, China is a socialist country in which public ownership plays the leading role in its economy. If state ownership is abolished, enterprises would take properties as their own, and the property owned by people would become "collectively owned." The state would no longer be the subject of the ownership. There would be no macro-control over the whole economy by the state through the legal system of ownership. It would easily lead to spontaneous tendencies of decentralization and blindness in the economy and disregard for the general interest.

The authors consider that given the goals of China's planned commodity economy, the state enterprise, as a commodity producer, must be granted necessary property rights. The enterprise must have the right to possess, utilize, profit from, and dispose of the property. Under the theory of Marxism, the precondition for the existence of a commodity economy is that the producer consider itself as the commodity owner and as having an ownership right in exchange, transfer, and acquisition. Therefore, if the enterprise is not an owner, and does not enjoy jurisdiction over the commodities produced, that is, the ownership rights of a legal person, then it has no right to act as an exchanger of commodities with the status of legal person, nor can it enter the sphere of exchange as a relatively independent commodity producer. This is one aspect of the problem. Another aspect is that the state enterprise that participates in the production and circulation of

37. Shen Meice, Lun qiye faren suoyouquan (On the Ownership Right of the Enterprise Legal Person), in Guojia suoyouquan lunivenji (Collected Essays on the State's Ownership Right) (1987). 
commodities may suffer losses, even to the point of bankruptcy. The enterprise must then assume its obligations with the property at its disposal. The reason that the enterprise can use its property to bear this liability is because it acts as a legal person which owns the property. Thus, recognizing that the socialist economy is a planned commodity economy, given that we want to develop the socialist commodity economy, recognition of the state enterprise as a legal person with the ownership rights of a legal person is inevitable.

The authors consider that the rights to possess, use, and dispose that are encompassed in the ownership right can, on the basis of the will and interests of the owner, be separated from ownership. This is required for the development of the commodity economy. These rights are the keys to production, exchange, distribution, and sale. The enterprise lacks any sort of competence to resolve the question of whether or not in production or reproduction the enterprise can achieve the status of a relatively independent producer and manager of commodities. Its role as a producer and manager of commodities and its position in law as a legal person are imperfect. Therefore, the so-called proper separation of state ownership refers to the proper separation of all powers and functions and not just some. When the enterprise enjoys various competencies, it already possesses the legal person ownership right. This then safeguards the enterprise's status as legal person. However, does it mean that the state ownership is abolished when the state separates its ownership from various functions deriving from the ownership? The authors hold that every function of the property right can be separated from the right itself. And this does not mean the ownership right is diminished. The reason is that aside from all functional rights dwelling in the ownership, there is another abstract right, the right of control, which only belongs to the owner. ${ }^{38}$ After the various functions of ownership are separated, the owner's right of control (zhipei quan), that is, the owner's authority over the things, is not separated from the owner. The right of dominance is perpetual because it belongs throughout to the owner. Regardless of how long these functional rights are separated from the ownership right, the separation is temporary; ultimately these rights reside in the ownership right. Those who worry that once functional rights are separated from ownership, the nature of state ownership in a socialist country will change, do not understand how to protect and promote socialist public ownership through means of law. Thus, we state again that recognition of the ownership rights enjoyed by the enterprise legal person in no way negates the ownership rights of the state.

What measure, if any, could be used to realize the goal of guaranteeing the separation of legal capacity from ownership and allowing the state enterprise to enjoy the ownership rights of legal person? The authors think that the methods adopted in the reform such as leasing, responsibility system, or 30

38. Concerning the disputes on the right of control, see Wang Liming \& Li Shirong, supra note 
capital responsibility system, cannot resolve the problem. Only gradual implementation of a joint stock system can attain the goal. (See part three of this article.) In China's current stage, a stock system can be implemented only in the small and medium size state enterprises. The state must maintain exclusive control and management of those large enterprises that affect the national economy and livelihood. The state shall also have exclusive right to their profits. The large enterprises could try the form of "one man company" to restructure their organization. Under such reorganization, a large enterprise would have only one stockholder, the state. In theory, however, the property directly controlled by the state could be separated from the property controlled by the enterprise. The enterprise would thus gain the status of legal person and bear civil liability on its own. The investment risk would thus be shifted to the enterprise from the state. Of course, our view is not consistent with the current legislation. It awaits proof through practice. ${ }^{39}$

\section{IV}

\section{Several Forms of Realization of the State Enterprise Property Right}

The aim of China's urban economic reform is to invigorate the enterprises. The key in this process is to affirm and protect the enterprise's property right. What sort of legal form should be adeopted to realize enterprise property rights? Over the last several years theoretical and practical workers have conducted a vigorous debate about this. Owing to the numbers and types of Chinese enterprises, theory and practice have produced various legal forms.

\section{A. Stock Equity}

Some of the state-owned enterprises have divided the property into a certain number of shares which could be bought by employees of the enterprise, members outside of the enterprises, collective units, or enterprises. The state has the controlling share. The form of stock equity has changed the situation where the state was the sole owner of the property. The new stock equity venture becomes a legal person, enjoying ownership right, while the control of the state is realized through the stocks it holds. As the owner of stock, the state has the right to profit from and dispose of it. Other rights will be exercised by the enterprise.

Since the independent property ownership right is derived from owning stock rather than from a unilateral administrative authorization by the state, the state, even though it is majority shareholder can no longer directly interfere with the operational activities of the enterprises. "The state can exercise its influence only through its shareholder rights and board

39. According to article 4 of "The Provisional Regulations on Administration of Company Registration" issued in 1985 by the State Council ("Gongsi dengji quanli zanxing guiding"), it is forbidden to establish a one-person company. 
membership."40 Thus, the right in property has become a stockholding right rather than an administrative right. This relationship is one protected by law. The right and liability in the property will be prescribed either by relevant regulations or by-laws of the enterprises. The rights and duties between the state as shareholder and the joint stock enterprise are thereby concrete and legally guaranteed.

To what kind of enterprises could the form of stock equity be applied? Some scholars hold that it is not applicable to large-scale enterprises that have a vital role in the national economy, such as banks, railroads, telephone companies, and postal services. But it could be applied to newly established specialized banks, railway companies, power companies, and communication companies. State owned large and medium enterprises can gradually implement limited liability equity enterprises. Newly established large and medium size enterprises ought all take the form of equity stock ventures. Joint ventures with foreign investment ought all be stock equity with limited liability. Other small scale enterprises are not well suited to adopt stock equity. ${ }^{41}$ Some other scholars, however, hold that the form of stock equity should not be the direction of reform for Chinese large and medium size enterprise. They hold that the stock system is for resolving contradictions between socialized production and relatively dispersed capital, and between various ownership forms. Under Chinese socialism,

the stock system could be used to collect capital by issuing stocks to the society to expand production and upgrade the socialization process of individual or collective enterprises. The large and medium size enterprises have already become publicly owned property, or as Marx said, direct social property. It is hard to say that becoming an equity system economy is economic progress. Therefore establishing such a system cannot be considered a goal or direction of the reform. ${ }^{42}$

In form, joint equity can realize the separation of ownership and management rights and guarantee the independent property rights of the enterprise. Yet, the system cannot effectively prevent state interference because as the largest stockholder in the enterprise, the members of the board of directors representing the interests of the state could select the chairman of the board, appoint the officers, control the direction of policy, and decide the management philosophy and allocation of resources. Under these circumstances, because stock powers are essentially concentrated in the hands of the state, not only would socialist large and medium scale enterprises not benefit from the separation of state and enterprise, but the state would also possibly have a legal basis for renewed interference in the enterprises' economic vitalization. ${ }^{43}$

40. Wan Yining, Wo guo suoyouzhi gaige de shexiang (Tentative Thoughts on Reform of Our System of Ownership), People's Daily, Sept. 26, 1986, at 5.

41. Id.

42. See Wu Shuqing, Gufenhua bushi guoying dazhongxing qiye gaige de fangxiang (Securitization is not the Direction of Enterprise Reform of Large- and Middle-Scale State Enterprises), People's Daily, Mar. 16, 1987, at 5.

43. Id. 
The stock equity system is a legal form that can serve to realize state enterprises' property rights, but that ought to be conditionally applied to only some. Still, generally speaking, among the various measures for perfecting the system of state enterprise property rights, it is theoretically the most possible. We consider that: (1) After an enterprise adopts the stock system, the state's administrative organs would no longer exercise ownership rights but would become organizations representing the will of the state and implementing its administrative rights. The state may establish special organizations to manage its equity interests and property in different enterprises (something similar to holding companies in the west). The institutions so established will have special reponsibility for the state's property and investment profit from the stocks, and for appointing representatives to the enterprises. The relationship between such institutions and enterprises should be as equal subjects, a father/son-like subordinate administrative relationship. This will encourage the separation of ownership and administrative rights and permit government organizations to escape the contradictions inherent in their dual functions. (2) After the state and some other entities have invested capital into the enterprise, they would lose direct control over the property but the enterprise would have the independent right over the property. It would become truly an independent equity enterprise legal person. (3) The stock equity system would cause the enterprise and laborers to feel a high degree of responsibility toward the property they occupy. Because stock equity absorbs part of its capital from individual laborers, those individuals would have risk in the capital they invested. The laborers, the enterprise, and the state are tied together on the property in which to share the risks. "If one loses, everyone loses. If one gains, everyone gains." It would change the state of mind for most of the people who did not care about the profit of the enterprise, and did not pay attention to the invasion of state property or waste of property. It could thus promote the most efficiency in utilizing the property. (4) In the stock system, the enterprise would no longer be able to get free use of capital and property from the state. The venture would have a certain risk. The state, as an investor, would have to care about the result/output of its capital. Whether the state could get a good return depends on the management of each enterprise. When an enterprise has a good rate of return, the state could put more capital into the enterprise by acquiring more shares of the enterprise so as to increase the amount of profit. For those enterprises that are illmanaged, the state could pull out the investment, reduce the shares of the stock, or transfer capital to the most needed places. In this way, state capital is invested more reasonably. Stock enterprises remain a complicated issue, and numerous questions await exploration. ${ }^{44}$

44. See Wang Liming \& Guo Feng, Guoyou qiye gufenhua yu guojia suoyouquan (Securitization of StateOwned Enterprises and the State's Ownership Rights), in Guoyou QIYE GUFENhua Yu guojIa SUOYOUQUAN DE biange (Securitization of State-OWned Enterprises and the Transformation of State OWNERSHIP Rights). 


\section{B. The Leasing System}

In the leasing system, the state would act as a traditional lessor to lease the enterprise to collectives, partnerships, or individuals. The lessor and one lessee would interact with each other according to the leasing contract. The state would not interfere with production activities, so long as they conformed to the law, and under the provisions of the lease contract, the lessee would have the independent right to possess, utilize, profit, and dispose of property in the enterprise. Accordingly, the enterprise's independent property right is directly embodied in the lessee itself. Such activity is the activity undertaken by the enterprise as an independent legal person. The independent property right is directly passed onto the lessee through the leasing contract. If the state violated the provisions of the leasing contract and infringed on this right, the enterprise could seek legal protection under the law. The leasing system thus helps to establish the property right for the enterprise.

In practice, there is no clear unified regulation regarding the leasing system for state-owned enterprises, and methods vary widely by locality. In general, the current leasing system has several features. First, the whole enterprise is the subject matter of the lease. The enterprise legal person's property right is exercised by the lessee. The state cannot interfere with the exercise of the property right. Second, the lessee implements the state plan under the lease contract. The lessee also pays taxes to the state. The lessee promotes the efficiency of the enterprise and develops the quality of the enterprise so as to increase and strengthen its productivity. But the lessee cannot change the direction of the enterprise without the authorization of the state. Third, when the lessee assumes the lease, he must provide certain security property as guarantee of completion of the contract's demands and as compensation to the state for losses it might suffer as a consequence of enterprise losses. However, since the lessee's economic strength is limited, the security property may be less than the total value of the property that is being leased. Fourth, leased enterprises are usually small industrial enterprises or small to medium commercial enterprises. This is because given lessees' limited ability to provide security, they lack the capacity to bear the responsibility for a large-scale enterprise's deficits or for losses the state would suffer from a bankruptcy. As a consequence, large and medium size enterprises are not easy to be leased out. ${ }^{45}$

The leasing system provides a possible resolution to the problem of enterprises' independent management of their property rights. It also eliminates unjust interference from the state. It reasonably adjusts the

45. On the above method, one can consult Shenyang shi xiaoxing guoying qiye zulin jingying guiding (Shenyang Municipal Proposed Regulations for Managment of Leasing of Small-Scale State Enterprises; Beijing shih guoying (jiti) xiaoxing xiuli qiye zulin jingying shixing guiding (Beijing Municipal Proposed Regulations for Management of Leasing of Small-Scale State and Collective Repair Enterprises); Shanghai shi guanyu guoying xiaoxing he jiti shangye shipin fuwuye zulin jingying shixing guiding (Shanghai Municipal Temporary Regulations on Several Questions Concerning Management of Leasing of Small-Scale State and Collective Commercial, Food, and Service Enterprises). 
distribution of interests between the state and the enterprise and creates the possibility for the lessee to obtain a large profit and assume economic obligations. Practice shows that the leasing system achieves fairly clear economic benefits.

We think, though, that the leasing system has its own shortcomings: First, in most of the cases, the lessee cannot bear the risks of unprofitable management. In other words, the leasing system would be efficient only when the enterprise is making a profit. If the enterprise were to run in the red, the state would sustain most of the losses. However, such problems can be solved by establishing a system of venture risk insurance. The coverage of such insurance shall be that part of the property that is not guaranteed by the security property provided by the lessee. The premium of such insurance shall be shared by the enterprise and the lessee. The lessee's share of the premium may be deducted from profits. The enterprise may pay for this portion of the premium before the enterprise starts making profit. Thus, the state can avoid losses to its property caused by the poor management of a lessee with insufficient capital.

Second, the short range behavior by the lessee may be overemphasized. Because the leasing system usually bases the reward to the lessee on annual profit, it may stimulate a tendency for the enterprise to seek only short range profit but disregard the longer range behavior within a limited lease period. To prevent such short-sighted behavior, the authors think that the lease contract should contain clear provisions on investment and improved technology and that the final reward for the lessee should be determined on the basis of the value of the property after the expiration of the leasing contract.

Third, the relationship between the lessee and the employees of the enterprise tends to be tense. This tension occurs because once the enterprise is leased out, employees' wages and hours and pace of work are all decided by the lessee. Since there are no determinate legal forms to control the lessee's actions, it would be easy for the employees' interests to be harmed and the relationship between the lessee and the employees to become tense. The authors think that the way to resolve this problem is to use labor, specifically labor contracts, to regulate the relationship between lessee and enterprise employees on such matters as work assignment, wages, and safety. Violations by either side would be dealt with according to law. In this way the lawful rights and interests of the workers may be assured, and to an extent relations between lessee and employees may be relaxed.

\section{Forms of Responsibility Contract}

The responsibility system is one in which the state contracts with the enterprise for the enterprise to undertake a series of economic and technical goals such as amount of profit, technical reform, new product development, product quality, consumption of supplies, equipment utilization rate, appreciation of fixed assets, efficiency of capital use, conditions for carrying 
out the plan, loan repayment, and production safety. The contract also provides that the enterprise enjoys complete rights to possess, use, and benefit from its property. The distinguishing feature of the responsibility system is that proceeding from the distribution of rights and interests, the enterprise obtains stipulated benefit once it has completed for the state the economic and technological goals called for in the contract. Thus, the state clearly and concretely embodies in the contract's provisions the economic and technical goals within the contents of the enterprise's ownership rights, while the state cannot interfere at will since within the stipulations of the contract the enterprise enjoys complete autonomy in regard to its property. Therefore, the responsibility system is the realization of the enterprise's property rights through the signing of a responsibility contract by the state and the enterprise.

Since responsibility contracts provide in concrete detail the economic and technical goals which the enterprise should achieve and protect the interests of both government and enterprise, such contracts play an active role in increasing the energy and realizing the property rights of the state-owned enterprise. Based on experimental units, the Chinese Government has spread responsibility contracts in big and medium state-owned enterprises since 1987. However, because the circumstances of enterprises are not uniform, various localities have adopted myriad types of contracts. Generally speaking, though, there are three kinds: 46

First, undertaking responsibility for progressively increasing payments. It means that the base amount and proportional rate of increase are fixed for several years. Its characteristics are: (1) The amount of profit paid to the state is fixed; anything in excess is kept by the enterprise. (2) The contract period is for several years. In exercising its property right, the enterprise must remember to engage in overall planning. (3) Through hard work, the enterprise can accumulate sufficient capital to develop new products and modernize its technology. (4) Since the share of profit paid to the state is fixed, the pressure and risk are great. This method requires the enterprise to have a sales outlet for its products, and relatively stable market and outside environment. So this system fits those companies with major responsibilities for technological reform and strong ability to export, or with an urgent need to develop, such as the Capital Iron and Steel Company and Number Two Motor Vehicle Company.

Second, undertaking responsibility for fixed profit payments. This means anything in excess of this amount is the enterprise's. The contract can be for one or more years. This form of contract fits those companies which produce products that are wanted by society but generate low profits. The enterprise gets a sufficient profit, but the state's income is low so the scope of such contracts should be restricted.

46. See Shijie jingji daobao (World Economic Herald), Apr. 27, 1987, at 13. 
Third, dividing the the profit surplus. It means that after the companies hand in the required amount of profit, they can share the remaining benefit with the government in a flexible period. With this kind of contract, both government and enterprise are able to benefit from the surplus. It carries less risk for both government and enterprise, and its applicable scope is relatively broad.

In the process of implementing the responsibility system, there are some places for improvement: how to calculate the enterprise's base value of property and base production; how to have the responsibility goals reflect the enterprise's interests. These economic issues can be resolved through gradual exploration and should not affect the realization of the independent property rights of enterprises. From the viewpoint of enterprise property rights, there are also some problems which need to be discussed, such as who owns the stipulated profit, and who has ownership if the companies use the excess profit to buy fixed assets. Some people say the newly gained assets should entirely or partly belong to the company; other people say they should belong completely to the state. ${ }^{47}$ The crucial question is how to determine the ownership of profit itself. If the provisions of contract are applicable, all the profit belongs to the enterprise and the ownership of the assets which are produced through reinvestment of the profit by the enterprise also belong to the same enterprise. But, the result of such a practice is that the whole assets of the enterprise, many years later, will be divided into two parts: state-owned assets and the enterprise's collectively owned assets. Furthermore, the percentage of the latter will be increasing with the continuous expansion of production. The result will change the basic nature of the ownership system and conflict with the fundamental requirements of China's system of socialist public ownership.

\section{$\mathrm{V}$}

\section{The Forms of Asset Management Responsibility System}

The asset management responsibility system is a combination of the reform of the leadership system of enterprises and the social evaluation of enterprise assets. It is a sort of legal form by which the enterprise's independent property right and responsibility for results passes through contract to the operator. ${ }^{48}$ The details of the form are the following:

1. To select enterprise leaders on the basis of existing tangible and intangible assets. The candidate assesses the potential productive ability of non-money capital and assets. The person whose assessment is highest and whose qualifications are good will be selected.

2. The competent organs of the state and the winning candidate negotiate, sign, and have notarized a contract that stipulates the rights, obligations, and responsibilities during the tenure of the candidate.

47. Id. at 14

48. Hua Shengchou, Weiguan jingjide chongxin gouzau (Rebuilding of Microeconomics), JINGJI YANJIU (ECONomic Research), No. 3 (1986); Chengshi gaigede hexin shi zhidude genben biange (The Core of Economic Reform is the Basic Transformation of the Enterprise System). Jingji ribao (Economic Daily), July i4, 1987. 
3. The candidate has to provide certain personal property to mortgage the loss of the capital and assets.

4. At the termination of the contract, the competent state organs reevaluate the enterprise assets and determine any differences. If there is a profit, the operator, staff, and workers are entitled to proportionate bonuses according to contract; if there is a loss, the manager, staff, and workers remediate the loss out of the operator's personal property and income and the staff's bonuses for that year, according to the same contractually stipulated proportions.

So, the focus of the asset management responsibility system is fixing the economic responsibility of the operator and through contract granting him the managerial right in the enterprise. The right of manager is in fact transferred from the independent right of enterprise property. All these elements are embodied in the contract, the realization of which is protected by law.

Is this form worth extending broadly? Can it be realized as effective? Many scholars doubt the applicability and effectiveness of asset management responsibility. Some hold that this system's focus is decentralization of power and intensification of responsibility; therefore, "asset management responsibility" is only about how to divide the same power into different levels and not about throwing out the old concept of "monopolizing big power, and dispersing little ones." Besides, under "asset management responsibility," enterprise and adminstrative departments are connected closely, and the policymaking in and operation of the social economy is under the tight control (in the sense that evaluation relates to control) of the state organization from the very beginning. This denies the economic function of the enterprise and inhibits the chief mechanism of an enterprise commodity economy. Therefore, it is hard to separate state and enterprise and to realize the enterprise's independent property right. ${ }^{49}$

Others argue that the main defect of asset management responsibility is the lack of a scientific basis for assessing of the assets of the enterprise. Influenced by people's subjectivity, assessments hardly reflect the real situation of the management and operation of the enterprise. It probably will also provide a chance for some people to take advantage of the government by embezzling, and disrupt normal social economic life. ${ }^{50}$

This form has been experimented with in more than 100 enterprises in over twenty cities including Shenyang, Zhongqing, Wuhan, Nanjing, and Yantai. ${ }^{51}$ From the experience of the experiments, this form of contract has a positive significance. But problems exist and need to be explored in areas such as choosing the operator, estimating the value of assets, converting assets to stocks, and determining remuneration of the operator and employees.

49. Luo Zhengfen, Dui zichan jingying zeren zhidude fansi (Second Thoughts on the Responsibility System of Capital Management), Jingji yanjIU (ECONOMic ResearCh), No. 11 (1986).

50. See Shi Qianlong, Qiye gufenhua gaizao gouxiang (An Outline of the Transformation of Enterprises by Securitization), Lilun xinxi bao (Theoretical News), Aug. 11, 1986, at 3.

51. Lilun xinxi bao (Theoretical News), Apr. 20, 1987, at 1. 
Some people suggest different legal forms, such as trusteeship or agency, for the enterprise to achieve the ownership of assets. ${ }^{52}$ The authors consider that since the forms, situations, and environments of state enterprises vary, we cannot tendentiously insist that they all adopt certain forms or choose and use the forms without discussing if these fit the special situation of the enterprises. The factual situation should be analyzed before adopting any forms. Besides the stock form, the rest of the forms adopt the model of separating state ownership and enterprise operation. These forms do not really give the enterprises ownership and do not secure the enterprises' independent position. The forms of lease, contract, and asset management responsibility usually increase the antagonism between the manager and the employee because these forms will increase the manager's authority and reduce the employee's right to manage the enterprise democratically. If the operator has the right to operate, and his inappropriate exercise of that right causes heavy losses, perhaps to the point of bankruptcy, the employees' interests will surely be adversely affected. It is unfair to let the employees to bear the consequences.

Taking the needs of the vitalization of enterprises and the development of the socialist commodities economy as the starting point, the property relations between the state and enterprise should be handled by adopting forms that separate the state's ownership right from the enterprise legal person's ownership right. It means that the enterprise's ownership right must first be established. Then part of the power and functions that inhere in the enterprise legal person's ownership right must be separated and granted to the enterprise legal person's lawful respresentative thereby separating within the enterprise its ownership right from the operator's management right. By adopting this form, the employee's enthusiasm can be mobilized and the internal management system of the enterprise established and perfected. Therefore, the authors think that compared with other forms, stockholding is a possible avenue.

\section{Conclusion}

China is a socialist state in which the means of production are publicly owned. The ownership of the state-owned enterprise is an important problem at present in the course of our economic reform. We can say that the economic reform in the cities of the entire country is unfolding around this key question. So the resolving of this question directly affects the progress and results of the reform.

The property rights of enterprises in a system of ownership by the whole is also an important theoretical question in our civil law that needs to be resolved. In one passage of his History of Theory of Surplus Value, Karl Marx

52. Zhang Yi, Luelun guoyou qiye gaigede fangxiang (A Brief Discussion of the Direction of Reform of Stateowned Enterprises), Guangming ribào (Guangming Daily), Dec. 6, 1986. 
approvingly quotes Montesquieu's famous statement that "the spirit of law is ownership." Ownership is the key question not only in civil law but also in all of law. As young Chinese scholars of law, we feel deeply the necessity to integrate China's practice of reform and to articulate our views on the state's ownership rights and the enterprise's property rights. We hope that leglislators will give them some attention and consider them a small contribution to reform. At the same time, we hope that foreign scholars will give the authors unstinting advice. 